\title{
Paenibacillus stellifer sp. nov., a cyclodextrin- producing species isolated from paperboard
}

Correspondence

Mirja Salkinoja-Salonen mirja.salkinoja-salonen@ helsinki.fi

\author{
Irmgard Suominen, ${ }^{1}$ Cathrin Spröer, ${ }^{2}$ Peter Kämpfer, ${ }^{3}$ Frederick A. Rainey, ${ }^{4}$ \\ Kari Lounatmaa ${ }^{5}$ and Mirja Salkinoja-Salonen ${ }^{1}$
}

\author{
${ }^{1}$ Department of Applied Chemistry and Microbiology, PO Box 56, FIN-00014 University of \\ Helsinki, Helsinki, Finland \\ ${ }^{2}$ German Collection of Micro-organisms and Cell Cultures, Mascheroder Weg 1b, D-38124 \\ Braunschweig, Germany \\ ${ }^{3}$ Institut für Angewandte Mikrobiologie, Justus-Liebig-Universität Giessen, Heinrich-Buff-Ring \\ 26-32, D-35392 Giessen, Germany \\ ${ }^{4}$ Department of Biological Sciences, 202 Life Sciences Building, Louisiana State University, \\ Baton Rouge, LA 70803, USA \\ ${ }^{5}$ Electronics Production Technology, PO Box 3000, FIN-02015 Helsinki University of \\ Technology, Helsinki, Finland
}

\begin{abstract}
The microflora isolated from food-packaging board is dominated by paenibacilli; a number of these micro-organisms have been characterized using a polyphasic approach. The highest 16S rRNA gene similarity was found between these isolates and Paenibacillus azotofixans ATCC $35681^{\top}$ $(97 \cdot 7 \%)$. The main fatty acid of the paperboard isolates was $C_{16: 0}(34-45 \%)$; straight-chain fatty acids made up $41-60 \%$ of the total cellular fatty acids, thus distinguishing these strains from other Paenibacillus species. The paperboard isolates produced cyclodextrins from starch. The spore surface had a characteristic ribbed ornamentation. Spores and vegetative cells frequently had pilus-like appendages. Based on phylogenetic data and phenotypic and chemotaxonomic characteristics, it is proposed that the isolates represent a novel species, Paenibacillus stellifer sp. nov., with IS $1^{\top}$ (=DSM $14472^{\top}=$ CCUG $\left.45566^{\top}\right)$ as the type strain.
\end{abstract}

Gram-positive spore-formers belonging to Bacillus or Paenibacillus are known as the main contaminants of food-packaging paper and board (Pirttijärvi et al., 1996; Suominen et al., 1997). The strains described in this paper represent the dominant and sometimes the sole contaminant of paperboard. Data show that the isolates represent a novel species within the genus Paenibacillus, for which the name Paenibacillus stellifer sp. nov. is proposed.

The novel isolates IS $1^{\mathrm{T}}$, IS 2, IS 3, IS 4 and IS 5 were obtained by plating homogenized food-packaging paperboard as described by TAPPI (1990) on brain heart infusion (BHI) agar (Difco) at $28^{\circ} \mathrm{C}$. The following reference strains were used: Paenibacillus azotofixans DSM 5976 ${ }^{\mathrm{T}}$, Paenibacillus borealis $\mathrm{KK} 19^{\mathrm{T}}$ (provided by S. Elo), Paenibacillus sp. KM8 (provided by S. Elo), Paenibacillus campinasensis KCTC

The EMBL accession numbers for the $16 \mathrm{~S}$ rDNA sequences of strains IS $1^{\top}$, IS 2 , IS 3 , IS 4 and IS 5 are respectively AJ316013 and AJ508713-AJ508716.

Detailed fatty acid compositions of individual novel isolates and P. polymyxa strains are available as supplementary material in IJSEM Online.
0364BP ${ }^{\mathrm{T}}$ (provided by J.-H. Yoon), Paenibacillus durus DSM 1735 ${ }^{\mathrm{T}}$, Paenibacillus lautus LMG $11157^{\mathrm{T}}$ and Paenibacillus polymyxa strains DSM $36^{\mathrm{T}}$, ATCC 7047 , NRRL B-369, NRRL B-375 and NRRL B-478.

Biochemical properties of strains grown on nutrient agar were determined as described by Elo et al. (2001) and by API 20NE and API 50CH (bioMérieux). Haemolysis was assayed on bovine blood agar plates prepared from tryptic soy agar (TSA) base (BBL) by adding $5 \%(\mathrm{v} / \mathrm{v})$ defibrinated bovine blood. Defibrination was achieved by adding $0.5 \%$ trisodium citrate dihydrate to the blood. Plates were read after 1 and 4 days at $28^{\circ} \mathrm{C}$ (Smibert \& Krieg, 1994). Cyclodextrin production from starch was tested as described by Pirttijärvi et al. (2001) and growth on cellulose, hemicellulose or xylan as sole carbon source $\left(10 \mathrm{~g} \mathrm{l}^{-1}\right)$ was tested on R2A medium (Clesceri et al., 1998) without glucose at $28^{\circ} \mathrm{C}$. Anaerobic growth was tested on $\mathrm{BHI}$ at $37^{\circ} \mathrm{C}$ for 5 days $\left(10 \% \mathrm{H}_{2}, 10 \%\right.$ $\mathrm{CO}_{2}, 80 \% \mathrm{~N}_{2}$ ).

Whole-cell fatty acid and $\mathrm{G}+\mathrm{C}$ content analysis and ribotyping were done as described by Elo et al. (2001). For ribotyping, a molecular size marker mixture $(1 \cdot 1,2 \cdot 2$, 
$3 \cdot 2,6 \cdot 5,9 \cdot 6$ and $48 \cdot 0 \mathrm{kbp})$ was run in slots adjacent to each sample slot.

Genomic DNA extraction, PCR-mediated amplification of the rRNA gene and purification of PCR products were carried out as described previously (Rainey et al., 1996). Purified PCR products were sequenced with Taq Dyedeoxy terminator cycle sequencing kits (Applied Biosystems) according to the manufacturer's protocol. An Applied Biosystems 373A DNA sequencer was used for electrophoresis of sequence reaction products. The ae2 editor (Maidak et al., 1999) was used to align the $16 \mathrm{~S}$ rRNA gene sequence determined in this study against $16 \mathrm{~S}$ rRNA gene sequences of representatives of Paenibacillus species available from public databases. Pairwise evolutionary distances were computed using the correction of Jukes \& Cantor (1969). The phylogenetic dendrogram was reconstructed from a distance matrix using the neighbour-joining treeing algorithm in the PHYLIP package (Felsenstein, 1993).

For negative staining, a 1-day-old culture grown on TSA (Difco) at $37^{\circ} \mathrm{C}$ was allowed to attach onto the carbon grid for $1 \mathrm{~min}$ and stained with $1 \%$ phosphotungstic acid $(\mathrm{pH} 7 \cdot 3$ ) for $25 \mathrm{~s}$. The grids were inspected on a JEOL 1200 EX TEM at an operating voltage of $60 \mathrm{kV}$. Cells grown on BHI plates for 4 days at $28^{\circ} \mathrm{C}$ were examined by TEM of thin sections, cells grown on TSA plates for 4 days at $28^{\circ} \mathrm{C}$ were observed by field emission SEM as described by Elo et al. (2001) and spores were studied by Hitachi S-4300 field emission SEM or JEOL JSM-6335F field emission SEM; voltages are given in the figure legends.

The Paenibacillus isolates originated from food-packaging paperboards for which the heterotrophic plate count was high in quality control analyses. They represent the main $(>90 \%)$ contaminant in paperboards and stored pulps containing ground wood. Vegetative cells were rod-shaped, $0 \cdot 6-0 \cdot 8 \times 2 \cdot 5-5 \cdot 0 \mu \mathrm{m}$. Young cells stained Gram-positive and were peritrichously flagellated (Fig. 1a). A thin section of vegetative cells showed S-layer-like material being shed from the cells (Fig. 1b). Thin sections of mature spores of the paperboard isolates showed six to seven 'spikes' on the surface (Fig. 1c), similar to spores of P. polymyxa (Murphy \& Campbell, 1969) and P. borealis (Elo et al., 2001). Field emission SEMs (Fig. 2a, b) reveal that the spikes were ribs ornamenting the spore surface. The ribs connected the poles of the spore (Fig. 2a). The rib pattern of the novel isolates was more similar to spores of the type strain of $P$. polymyxa (not shown in Fig. 2) than to those of $P$. borealis, in which the ornaments have a honeycomb appearance and are distributed uniformly over the spore (Elo et al., 2001). The isolates produced ellipsoidal spores in swollen sporangia in the terminal region of the cell (Fig. 1c). The spores visible in Fig. 2(a, b) were covered with a slimy looking material, removable from the spores with saline-peptone diluent $(0 \cdot 85 \% \mathrm{NaCl}, 0 \cdot 1 \%$ meat peptone) (Fig. 2c). Pilus-like appendages were observed on spores as well as on vegetative
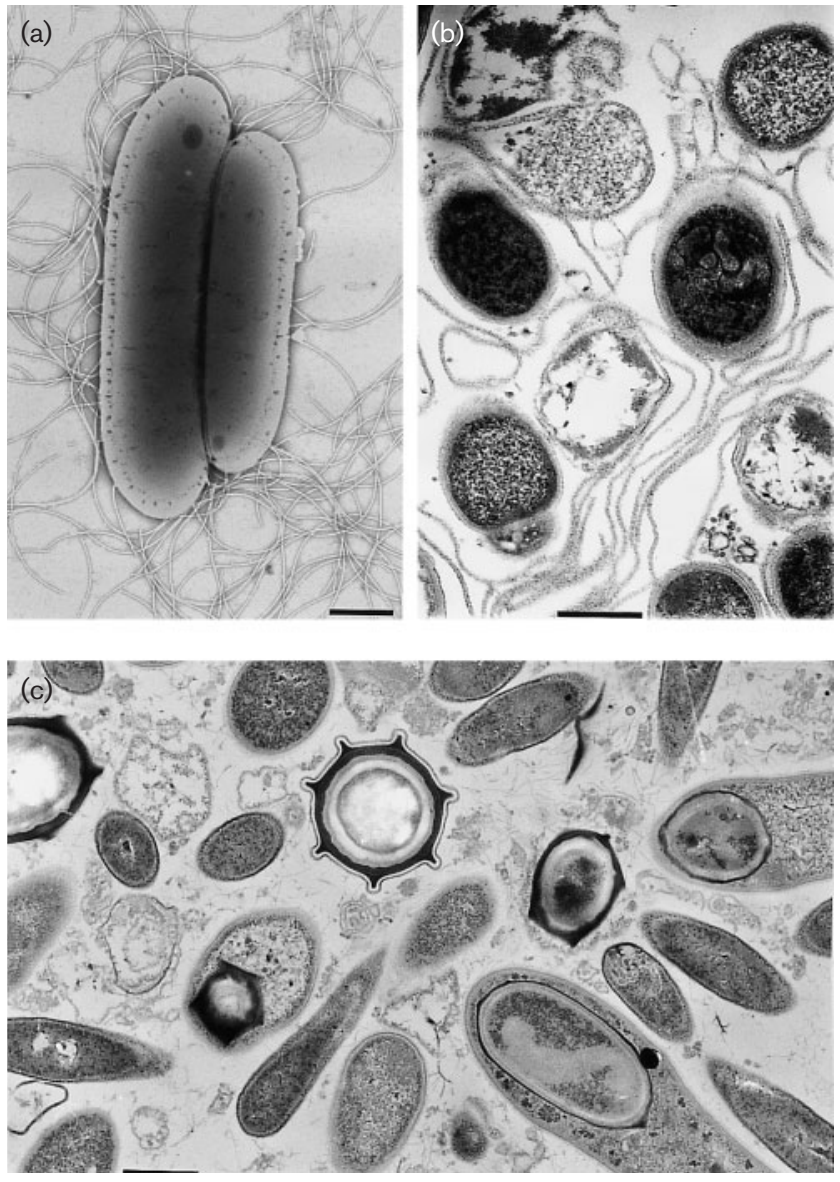

Fig. 1. (a) TEM of a 1-day-old culture of strain IS 5 after negative staining with $1 \%$ phosphotungstic acid. A high degree of peritrichous flagellation is visible. (b) Thin section of strain IS $1^{\top}$ showing S-layer material being shed from vegetative cells. Sections were prepared from a colony cut from an TSA plate grown for 3 days at $28^{\circ} \mathrm{C}$. Shedding of S-layers may occur when cells are in contact with a solid surface. Operating voltage, $60 \mathrm{kV}$. (c) TEM of strain IS 5 from a 4-day-old culture showing vegetative cells and spores at different stages of maturation. Operating voltage, $60 \mathrm{kV}$. Bars, $500 \mathrm{~nm}$.

cells (Fig. 2a). Appendages of similar morphology have been described for spores of Bacillus cereus (Kozuka \& Tochikubo, 1985; Mizuki et al., 1998), but not as yet for paenibacilli. Fig. 2(b) shows laminar material located on the spores; this material was shed during maturation of the spores and may represent the same material visible as the 'S-layer' in thin sections (Fig. 1b).

The isolates grew aerobically at $15-40{ }^{\circ} \mathrm{C}$ and anaerobically on BHI at $37^{\circ} \mathrm{C}$. The whole-cell fatty acid compositions of the paperboard isolates (grown at $28^{\circ} \mathrm{C}$ ) and phylogenetically related Paenibacillus species are summarized in Table 1; detailed fatty acid compositions of individual novel isolates and $P$. polymyxa strains are available as supplementary material in IJSEM Online. The main 

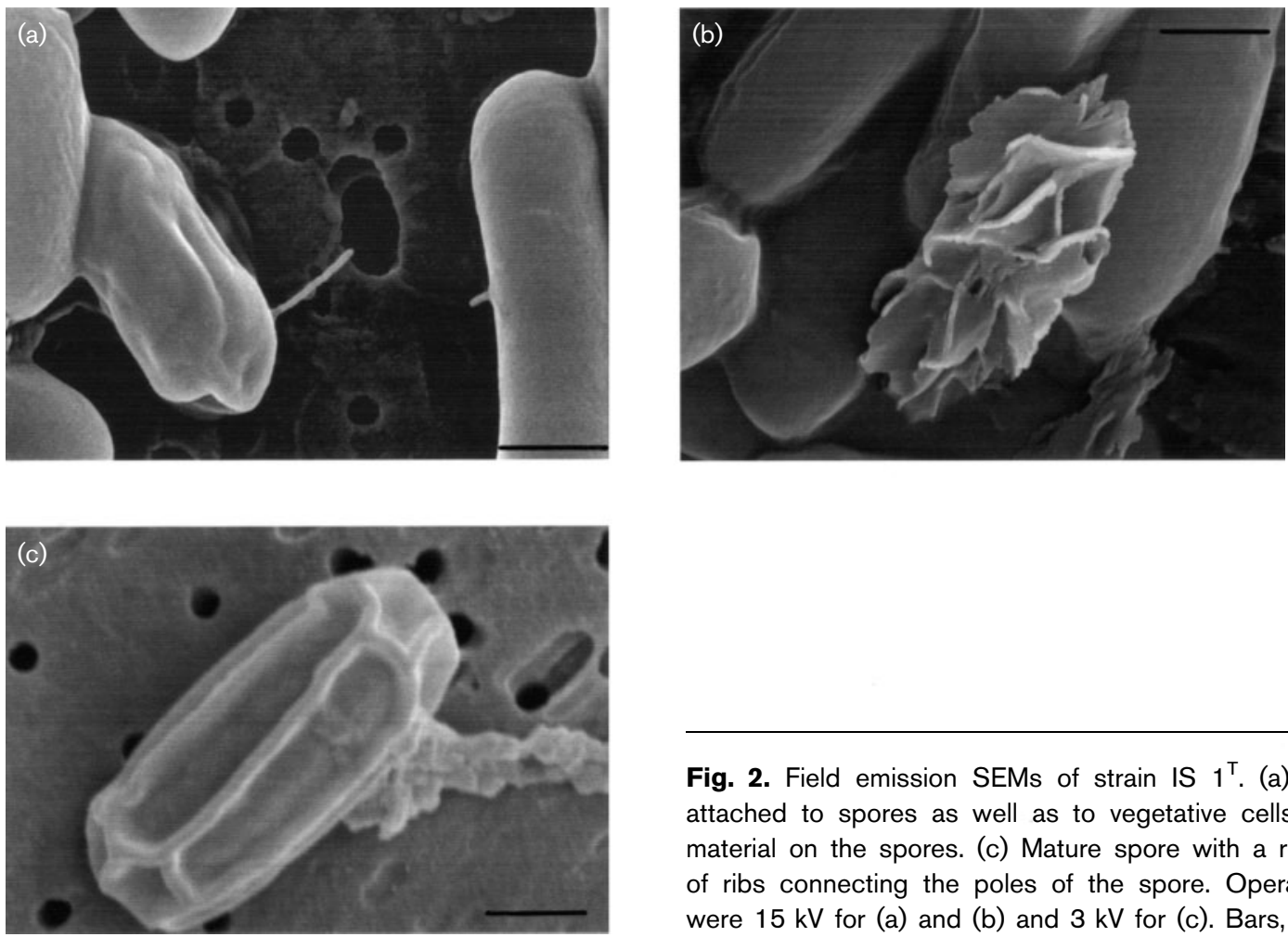

Fig. 2. Field emission SEMs of strain IS $1^{\top}$. (a) Appendages attached to spores as well as to vegetative cells. (b) Layered material on the spores. (c) Mature spore with a regular pattern of ribs connecting the poles of the spore. Operating voltages were $15 \mathrm{kV}$ for (a) and (b) and $3 \mathrm{kV}$ for (c). Bars, $500 \mathrm{~nm}$.

Table 1. Whole-cell fatty acid compositions of the novel isolates and selected Paenibacillus strains

Values are percentages of total cellular fatty acids, with means (ranges) given for the novel isolates and $P$. polymyxa. Strains/taxa: 1, novel isolates $(n=5) ; 2$, P. azotofixans DSM 5976 ; 3, P. borealis KK19 ${ }^{\mathrm{T}}$; 4, Paenibacillus sp. KM8; 5, P. campinasensis KCTC 0364BP ${ }^{\mathrm{T}}$; 6 , P. durus DSM $1735^{\mathrm{T}} ; 7$, P. lautus LMG $11157^{\mathrm{T}} ; 8$, P. polymyxa $(n=5)$. Detailed fatty acid compositions of individual novel isolates and $P$. polymyxa strains are available as supplementary material in IJSEM Online.

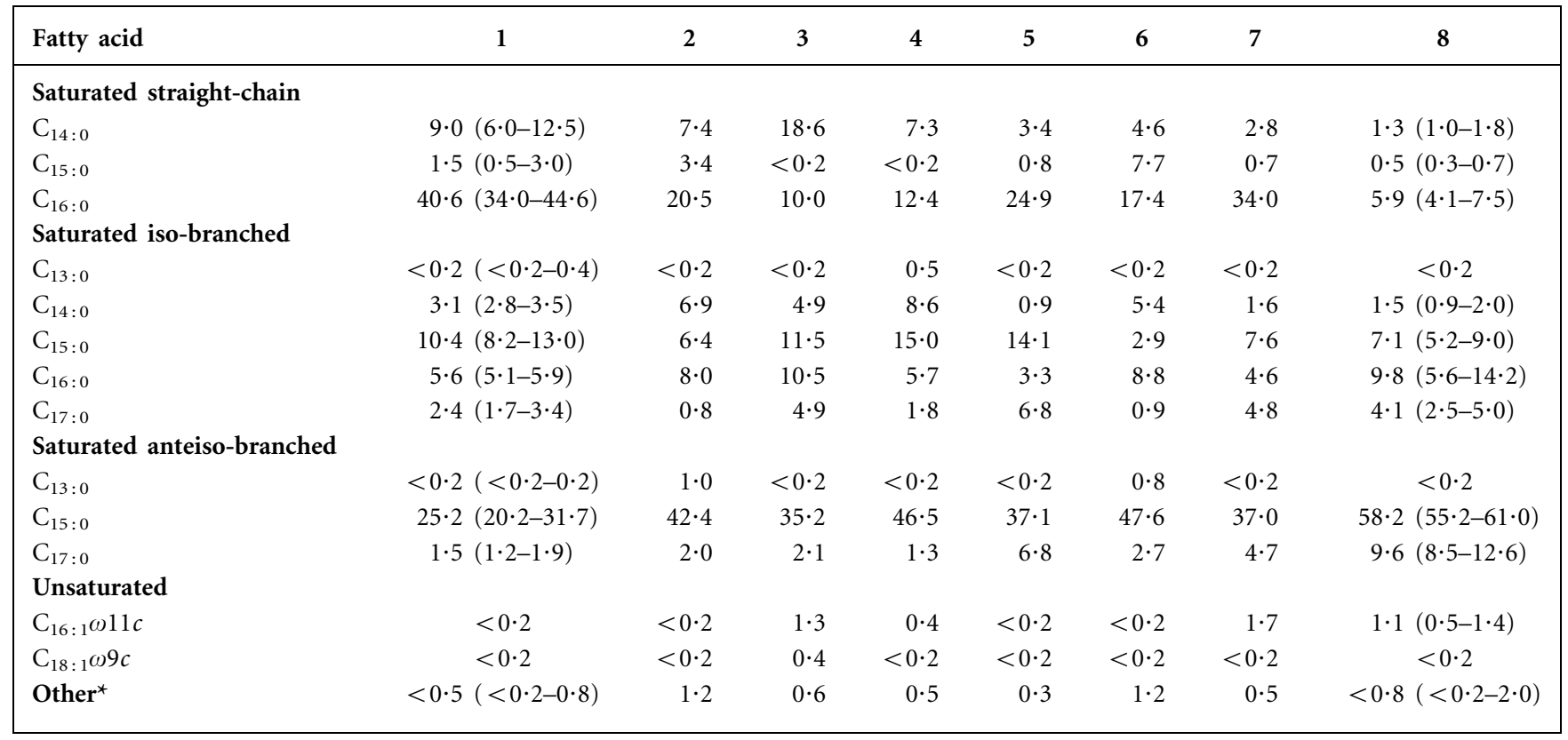

${ }^{*}$ Includes $\mathrm{C}_{12: 0}, \mathrm{C}_{16: 1} \omega 7 c$ alcohol, $\mathrm{C}_{17: 0}, \mathrm{C}_{17: 1}$ iso $\omega 10 c, \mathrm{C}_{17: 1}$ iso I/anteiso $\mathrm{B}, \mathrm{C}_{17: 1}$ anteiso $\mathrm{B} /$ iso $\mathrm{I}$ and $\mathrm{C}_{18: 0}$. 
fatty acid (34-45\%) of the paperboard isolates was $C_{16: 0}$, thus differentiating the paperboard isolates from all Paenibacillus species except $P$. lautus. Straight-chain fatty acids in the paperboard isolates made up $41-60 \%$ total fatty acids, whereas, for the other paenibacilli, this sum was $<40 \%$. The iso: anteiso ratio was lower $(2 \cdot 3-2 \cdot 5)$ for the paperboard isolates and their phylogenetic relatives $P$. azotofixans, $P$. borealis and $P$. durus than for other Paenibacillus species (including P. lautus), where it was $3 \cdot 1-16 \cdot 4$.

The novel isolates differed from P. azotofixans, $P$. durus and $P$. borealis in gluconate assimilation and hydrolysis of $\mathrm{pNP}$ $\beta$-D-galactopyranoside and L-proline pNA (Table 2). The novel isolates had similar reactions to $P$. azotofixans, $P$. durus and $P$. borealis for 48 of the 65 tested substrates. Additional tests were performed for the novel isolates, and results are given in Table 2. The isolates were catalase-positive, oxidase-negative and did not reduce nitrate to nitrite or nitrogen. None of the isolates showed haemolytic activity. Carboxymethylcellulose, hemicellulose and xylan were not used as sole carbon sources by the paperboard isolates. The five isolates degraded starch and produced cyclodextrins (Fig. 3), an important pathway for spoiling starch in the paper industry (Pirttijärvi et al., 2001). The isolates represent a novel taxon with starch-degrading properties in the paper machine environment. van der Maarel et al. (2000) described a starch-degrading Paenibacillus species, Paenibacillus granivorans, but it is not known whether it produces cyclodextrins.

The ribofragment patterns (Fig. 4) obtained for the isolates by EcoRI and PvuII digestion differed clearly from those of phylogenetically closely related species ( $P$. borealis, Paenibacillus sp. KM8, P. campinasensis, P. azotofixans, $P$. lautus, $P$. polymyxa, $P$. durus). The patterns generated for isolates IS $1^{\mathrm{T}}$, IS 2 and IS 4 with $P v u$ II were identical, and these strains shared seven bands with IS 3 and eight bands with IS 5. With EcoRI, all strains shared nine of 11 bands. Isolates IS 2 and IS 4 had identical EcoRI and PvuII ribotypes and shared identical whole-cell fatty acid compositions, indicating that they may be clones. Isolates IS $1^{\mathrm{T}}$, IS 3 and IS 5 each had a different combination of EcoRI and PvuI ribotypes, demonstrating they were isolates representing independent strains.

An almost-complete 16S rRNA gene sequence of 1519 nt (positions 27-1532, Escherichia coli numbering; Brosius et al., 1978) was determined for strain IS $1^{\mathrm{T}}$. Phylogenetic analyses based on a dataset consisting of 1255 unambiguous nucleotides between positions 45 and 1431 showed that strain IS $1^{\mathrm{T}}$ represented a novel lineage within the radiation of the genus Paenibacillus (Fig. 5). Pairwise similarity values ranged between 90.0\% (Paenibacillus kobensis IFO $15729^{\mathrm{T}}$, Paenibacillus dendritiformis $\left.\mathrm{T}_{168}{ }^{\mathrm{T}}\right)$ and $96 \cdot 8 \% \quad(P$. borealis DSM $\left.18188^{\mathrm{T}}\right)$. This novel lineage clusters with $P$. azotofixans (Seldin et al., 1984), P. borealis, Paenibacillus odorifer and Paenibacillus graminis, having 97·7, 97·2, 97.4 and
Table 2. Biochemical characteristics of the novel isolates and type strains of selected Paenibacillus species

Strains: 1, paperboard isolates $(n=5) ; 2, P$. azotofixans DSM $5976^{\mathrm{T}}$; 3, P. durus DSM $1735^{\mathrm{T}}$; 4, P. borealis $\mathrm{KK} 19^{\mathrm{T}}$. None of the strains utilized L-rhamnose, D-ribose, adonitol, i-inositol, putrescine, propionate, cis-aconitate, citrate, fumarate, 2-oxoglutarate, adipate, 4-aminobutyrate, azelate, glutarate, DL-3-hydroxybutyrate, itaconate, DL-lactate, mesaconate, suberate, L-alanine, $\beta$-alanine, L-aspartate, L-histidine, L-leucine, L-ornithine, L-phenylalanine, L-proline, L-serine, L-tryptophan, 3-hydroxybenzoate or phenylacetate. Strains IS $1^{\mathrm{T}}$, IS 2 , IS 3 , IS 4 and IS 5 did not utilize glycerol, erythritol, D-arabinose, methyl $\beta$-D-xyloside, L-sorbose, dulcitol, methyl $\alpha$-D-mannoside, methyl $\alpha$-D-glucoside, inulin, melezitose, xylitol, D-lyxose, D-tagatose, D-fucose, L-fucose, D-arabitol, L-arabitol, 2-ketogluconate or 5-ketogluconate. All strains utilized D-fructose, D-galactose, D-glucose, D-mannose, D-maltose, $\alpha$-D-melibiose, D-sucrose, salicin and D-trehalose. Strains IS $1^{\mathrm{T}}$, IS 2 , IS 3 , IS 4 and IS 5 utilized L-xylose, amygdalin, lactose, D-raffinose, starch, glycogen, $\beta$-gentiobiose and $\mathrm{D}$-turanose. Strains $\mathrm{IS} \mathrm{1}^{\mathrm{T}}$, IS 2 , IS 3 , IS 4 and IS 5 did not assimilate glucose, arabinose, mannose, mannitol, $\mathrm{N}$-acetylglucosamine, maltose, gluconate, caprate, adipate, malate, citrate or phenylacetate. All strains hydrolysed aesculin and pNP $\beta$-D-glucopyranoside. None of the strains hydrolysed pNP $\beta$-D-glucuronide, pNP phenylphosphonate, pNP phosphorylcholine, 2-deoxythymidine- $5^{\prime}$-pNP phosphate, L-alanine pNA or L-glutamate- $\gamma$-carboxy pNA. pNP, p-nitrophenyl; pNA, $p$-nitroanilide.

\begin{tabular}{|c|c|c|c|c|}
\hline Characteristic & 1 & 2 & 3 & 4 \\
\hline \multicolumn{5}{|l|}{ Assimilation of: } \\
\hline N-Acetyl-D-glucosamine & - & - & - & + \\
\hline L-Arabinose & + & - & - & + \\
\hline$p$-Arbutin & - & - & - & + \\
\hline D-Cellobiose & + & - & + & + \\
\hline Gluconate & - & + & + & + \\
\hline D-Xylose & + & - & - & + \\
\hline Maltitol & - & + & + & + \\
\hline D-Mannitol & - & - & + & - \\
\hline D-Sorbitol & - & + & - & + \\
\hline Acetate & - & + & - & - \\
\hline L-Malate & - & - & - & + \\
\hline Pyruvate & - & + & + & - \\
\hline 4-Hydroxybenzoate & - & - & + & - \\
\hline \multicolumn{5}{|l|}{ Hydrolysis of: } \\
\hline pNP $\beta$-D-galactopyranoside & + & - & - & - \\
\hline pNP $\alpha$-glucopyranoside & - & + & - & + \\
\hline bis-pNP phosphate & - & - & + & + \\
\hline L-Proline pNA & + & - & - & - \\
\hline
\end{tabular}

$95 \cdot 2 \% 16 \mathrm{~S}$ rRNA gene sequence similarity, respectively, to these species. In partial sequence analysis (497 nt; positions $24-510$, E. coli numbering), strain IS 5 showed $99 \cdot 6 \%$ similarity to strains IS $1^{\mathrm{T}}$, IS 2 , IS 3 and IS 4; the latter four strains were $100 \%$ similar to each other. This indicates that all five strains belong to one 


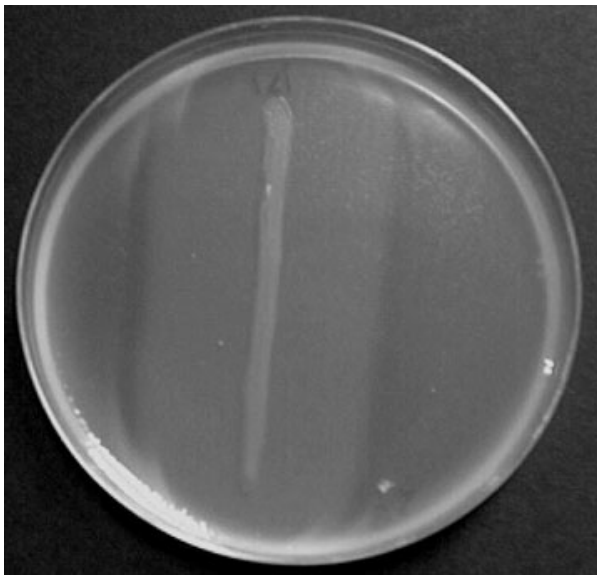

Fig. 3. Production of cyclodextrins by strain IS $1^{\top}$ on a starch plate. Cyclodextrins precipitated as a zone inside the clearing zone where starch was hydrolysed.

species. The DNA $\mathrm{G}+\mathrm{C}$ content of strain IS $1^{\mathrm{T}}$ was $55 \cdot 6 \mathrm{~mol} \%$.

The novel isolates can be distinguished from their closest phylogenetic relatives by whole-cell fatty acid composition, ribotyping with EcoRI or PvuII, assimilation of gluconate and hydrolysis of pNP $\beta$-D-galactopyranoside and L-proline pNA.

\section{Description of Paenibacillus stellifer sp. nov.}

Paenibacillus stellifer (stel'li.fer. L. adj. stellifer star-carrying, referring to the presence of star-shaped spores).

Gram-positive, facultatively anaerobic rods $(0 \cdot 6-0 \cdot 8 \times$ $2 \cdot 5-5 \cdot 0 \mu \mathrm{m})$, motile by means of peritrichous flagella. Ellipsoidal endospores form in swollen sporangia in the terminal region of the cell. Mature spores have a rib pattern connecting the poles of the spore. Spores as well as vegetative cells have pilus-like appendages. Biochemical features are specified in Table 2. The temperature range for growth is $15-40{ }^{\circ} \mathrm{C}$. Non-haemolytic. Catalase-positive. Oxidasenegative. Nitrate is not reduced to nitrite or nitrogen. The DNA G $+\mathrm{C}$ content of the type strain is $55.6 \mathrm{~mol} \%$. The major fatty acid is $\mathrm{C}_{16: 0}$ (34-45\% total fatty acids) and the ratio of $\mathrm{C}_{15: 0}$ iso : anteiso $\left(28^{\circ} \mathrm{C}\right)$ is $2 \cdot 3-2 \cdot 5$. Produces cyclodextrins from potato starch.

The type strain, IS $1^{\mathrm{T}}\left(=\mathrm{DSM} 14472^{\mathrm{T}}=\right.$ CCUG $\left.45566^{\mathrm{T}}\right)$, was isolated from food-packaging paperboard.

\section{Acknowledgements}

We thank Dr Ewald Denner and Professor Hans G. Trüper for advice, Jyrki Juhanoja and Juha Mentu for collaboration, Ina Kramer and Riitta Saastamoinen for excellent technical assistance and Viikki Scientific Library and Faculty Instrument Center for services. We thank Tekes Pinta programme for financial support. (a)

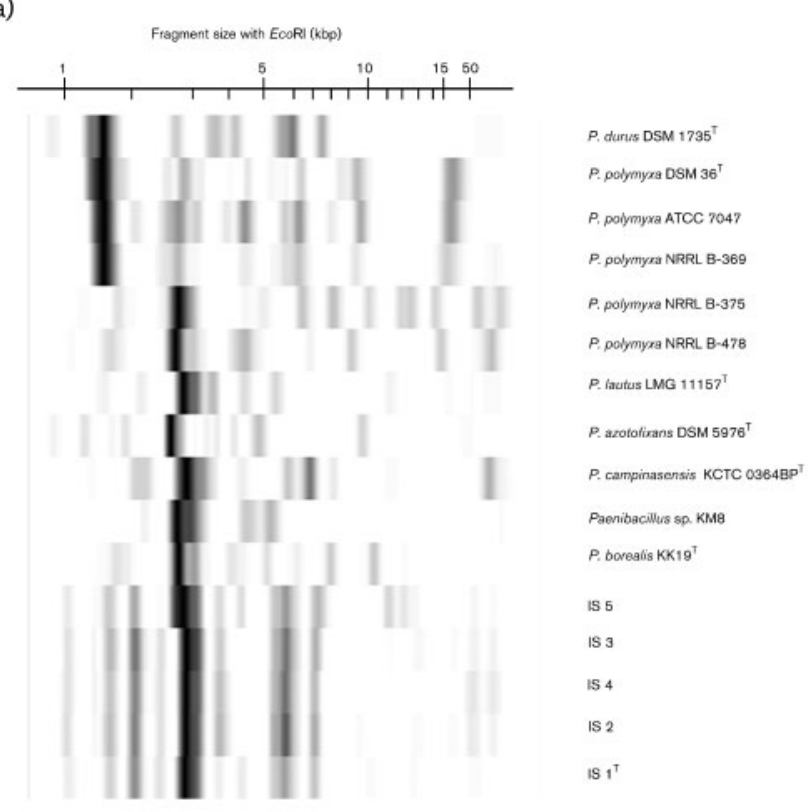

(b)

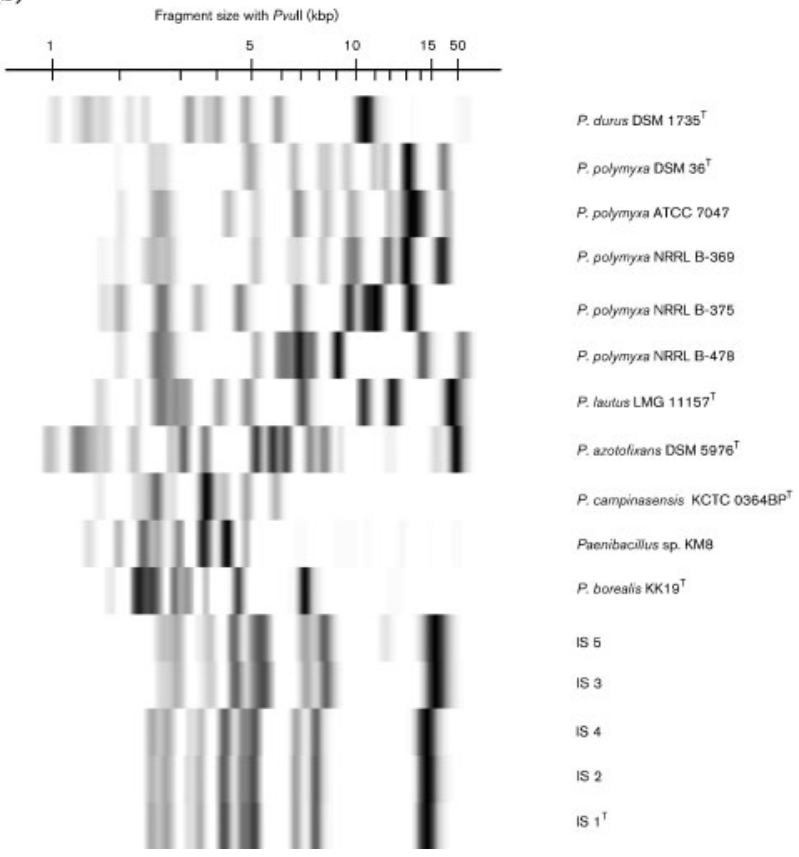

Fig. 4. Ribotyping of the five novel isolates and 11 Paenibacillus reference strains cut with EcoRI (a) and Pvull (b). Fragments are shown that hybridized with a phosphorescently labelled probe containing the $E$. coli operon of $5 S, 16 S$ and $23 S$ rRNA genes and the intergenic regions. 


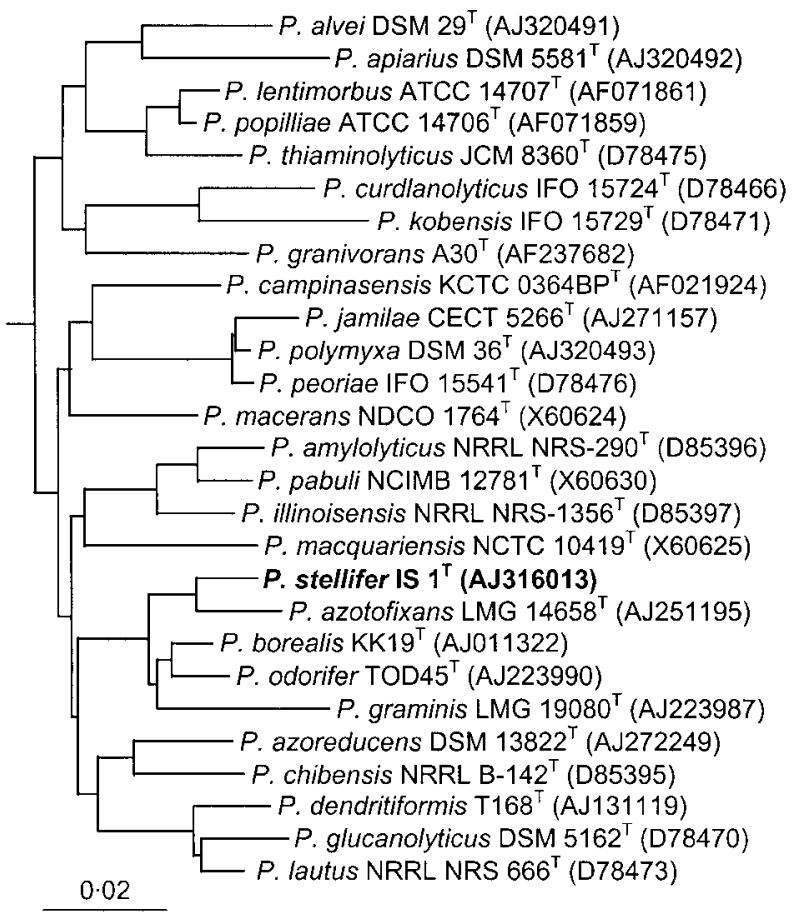

Fig. 5. Neighbour-joining tree of $16 \mathrm{~S}$ rDNAs showing the phylogenetic position of strain IS $1^{\top}$ compared with species of the genus Paenibacillus. Sequences were selected from a comparison with $16 \mathrm{~S}$ rDNA sequences of all described Paenibacillus species. Sequences of members of the Bacillus/ Staphylococcus group were used to root the dendrogram. Bootstrap analyses were made with 100 cycles. Bar, 2 substitutions per 100 nt.

\section{References}

Brosius, J., Palmer, M. L., Kennedy, P. J. \& Noller, H. F. (1978). Complete nucleotide sequence of a $16 \mathrm{~S}$ ribosomal RNA gene from Escherichia coli. Proc Natl Acad Sci U S A 75, 4801-4805.

Clesceri, L. S., Greenberg, A. E. \& Eaton, A. D. (1998). Microbiological examination - heterotrophic plate count. In Standard Methods for the Examination of Water and Wastewater, 20th edn, pp. 9-34-9-36. Washington, DC: American Public Health Association.

Elo, S., Suominen, I., Kämpfer, P., Juhanoja, J., Salkinoja-Salonen, M. \& Haahtela, K. (2001). Paenibacillus borealis sp. nov., a nitrogen-fixing species isolated from spruce forest humus in Finland. Int J Syst Evol Microbiol 51, 535-545.

Felsenstein, J. (1993). PHYLIP (phylogenetic inference package) version 3.5.1. Department of Genetics, University of Washington, Seattle, USA.

Jukes, T. H. \& Cantor, C. R. (1969). Evolution of protein molecules. In Mammalian Protein Metabolism, vol. 3, pp. 21-132. Edited by H. N. Munro. New York: Academic Press.

Kozuka, S. \& Tochikubo, K. (1985). Properties and origin of filamentous appendages on spores of Bacillus cereus. Microbiol Immunol 29, 21-37.

Maidak, B. L., Cole, J. R., Parker, C. T., Jr \& 11 other authors (1999). A new version of the RDP (Ribosomal Database Project). Nucleic Acids Res 27, 171-173.

Mizuki, E., Ohba, M., Ichimatsu, T., Hwang, S.-H., Higuchi, K., Saitoh, H. \& Akao, T. (1998). Unique appendages associated with spores of Bacillus cereus isolates. J Basic Microbiol 38, 33-39.

Murphy, J. A. \& Campbell, L. L. (1969). Surface features of Bacillus polymyxa spores as revealed by scanning electron microscopy. J Bacteriol 98, 737-743.

Pirttijärvi, T. S. M., Graeffe, T. H. \& Salkinoja-Salonen, M. S. (1996). Bacterial contaminants in liquid packaging boards: assessment of potential for food spoilage. J Appl Bacteriol 81, 445-458.

Pirttijärvi, T. S. M., Wahlström, G., Rainey, F. A., Saris, P. E. J. \& Salkinoja-Salonen, M. S. (2001). Inhibition of bacilli in industrial starches by nisin. J Ind Microbiol Biotechnol 26, 107-114.

Rainey, F. A., Ward-Rainey, N., Kroppenstedt, R. M. \& Stackebrandt, E. (1996). The genus Nocardiopsis represents a phylogenetically coherent taxon and a distinct actinomycete lineage: proposal of Nocardiopsaceae fam. nov. Int J Syst Bacteriol 46, 1088-1092.

Seldin, L., Van Elsas, J. D. \& Penido, E. G. C. (1984). Bacillus azotofixans sp. nov., a nitrogen-fixing species from Brazilian soils and grass roots. Int J Syst Bacteriol 34, 451-456.

Smibert, R. M. \& Krieg, N. R. (1994). Phenotypic characterization. In Methods for General and Molecular Bacteriology, pp. 607-654. Edited by P. Gerhardt, R. G. E. Murray, W. A. Wood \& N. R. Krieg. Washington, DC: American Society for Microbiology.

Suominen, I., Suihko, M.-L. \& Salkinoja-Salonen, M. (1997). Microscopic study of migration of microbes in food-packaging paper and board. J Ind Microbiol Biotechnol 19, 104-113.

TAPPI (1990). Bacteriological examination of paper and board. TAPPI standard T449 om-90. Atlanta: Technical Association of Pulp and Paper.

van der Maarel, M. J. E. C., Veen, A. \& Wijbenga, D. J. (2000). Paenibacillus granivorans sp. nov., a new Paenibacillus species which degrades native potato starch granules. Syst Appl Microbiol 23, 344-348. 